\title{
Screening of deodorizing active compounds from natural materials and deodorizing properties of cineole
}

\author{
Atsushi HENMI ${ }^{1}$, Tsutomu SUGINO ${ }^{1}$, Kenichi NAKAMURA ${ }^{1}$, \\ Masato NOMURA ${ }^{2}$ and Masakuni OKUHARA ${ }^{1 *}$ \\ ${ }^{1}$ Rilis Co., Ltd., 5-13-7 Niitaka, Yodogawa-ku, Osaka-shi, Osaka, 532-0033, Japan \\ ${ }^{2}$ Former professor in the Faculty of Engineering at Kindai University, \\ 1-1 Umenobe, Takaya, Higashihiroshima, Hiroshima, 739-2116, Japan
}

\begin{abstract}
Plant extracts were screened to identify novel deodorizing natural products. Deodorizing activity was detected in an aqueous ethanol extract of cluster mallow leaves by measuring headspace gas by GC (deodorizing activity was defined as percent reduction in headspace odorant concentration following deodorant addition in vitro.). The deodorant compound was purified using silica gel column chromatography, and the active principle was identified as 1,8-cineole by GC/MS analysis. 1,8-Cineole strongly deodorized $(>90 \%)$ a relatively wide range of odorous gases, including 2-nonenal, skatole, dimethyl trisulfide, indole, isovaleric acid, and dimethyl disulfide. The compounds also moderately deodorized $(>70 \%)$ allyl methyl sulfide, n-butyric acid, allyl mercaptan, and dimethyl sulfide. Organoleptic assessment conducted by sniffing headspace gas showed a reduction in odor score of 1.5 to 3. Correlative relationships were observed between 1,8-cinole's deodorizing activity and odorant molecular weight and boiling point. Furthermore, odorants adsorbed onto 1,8-cineole desorbed with increasing temperature, suggesting a physical deodorizing mechanism of cineole. Cineole is known to mask or hide ambient odorants by overwhelming the malodor with pleasant odor. Our study suggests that in addition to odor-masking activity, 1,8-cineole exhibits another deodorizing mechanism in which the gaseous odorant concentration is reduced via adsorption involving physical interaction between 1,8-cineole and odorant molecules. 1,8-Cinole may thus serve as an effective agent for eliminating various unpleasant odors.
\end{abstract}

\section{Introduction}

In recent years, large-scale industries such as livestock agriculture, food processing, and wastewater treatment have expanded greatly. These industries often generate numerous types of unpleasant odors, sometimes resulting in complaints from nearby residents. Open-air incineration and restaurants (e.g., beef barbecue restaurants) become sources of odor-related complaints in some cases. In the course of daily life at home, we also often experience unpleasant odors. These odors can arise from a variety of sources, including pet waste, spoiled food (e.g., rotten onions/fish), and raw garbage. Unpleasant breath odor is also experienced at some time in our lives.

Odorous gases have a variety of chemical structures, and include aldehydes, esters, nitrogen-/sulfur-bearing compounds, and short-chain fatty acids. The number of odor compounds is estimated at over $400,000^{1}$. Odor control methods can be classified into 4 categories, depending on the deodorizing mechanism: (1) physical methods, such as the use of activated carbon or silica gel to absorb malodorous compounds; (2) biological methods, such as the use of sanitizers that inactivate malodor-producing bacteria; (3) chemical methods, which involve chemical inactivation of malodorous compounds; and (4) sensory methods, which involve masking unpleasant odors with fragrances.

Deodorant manufacturers have developed a variety of products employing these mechanisms. For example, green tea, whose primary components are polyphenols (catechins) such as (-)-epigallocatechin gallate, (-)epigallocatechin, (-)-epicatechin gallate, and gallic acid, exhibits potent deodorizing activity ${ }^{2}$; thus, deodorant products containing green tea catechins are widely used. Kaki-tannin, the primary ingredient in astringent persimmon fruit, is also widely used in Japan and Southeast Asia for breath odor-neutralizing supple-

${ }^{*}$ Corresponding author : E-mail : okuhara@rilis.co.jp 


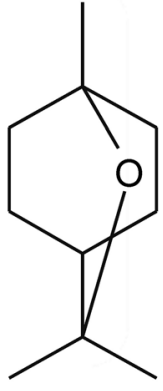

1,8-Cineole

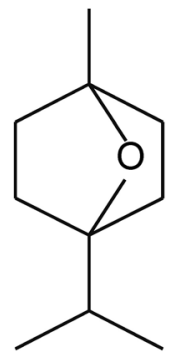

1,4-Cineole
Fig. 1 Structures of 1,8-cineole and 1,4-cineole.

ments, chewing gums, air fresheners, pet deodorants, deodorant lotions, etc. ${ }^{3)}$. The deodorization mechanisms of polyphenolic compounds are reportedly chemical reactions including addition, degradation, and replacement $t^{4) 5)}$. Several sulfur-containing gases arising from vegetables of the Allium species can be reduced chemically or physicochemically by raw foods such as fruits, vegetables, and mushrooms ${ }^{6}$ (we will cover this point in more detail below). Among the odorous gases associated with breath odor, including garlic breath (i.e., an unpleasant odor released after garlic consumption), hydrogen sulfide (HS) and methyl mercaptan (MM) are almost totally deodorized by green tea in vitro, and the levels of these odors are reduced significantly in vivo ${ }^{2)}$, while allyl methyl sulfide (AMS) is poorly deodorized compared with HS and MM in vitro and in vivo ${ }^{7}$. As such, compounds with potent deodorizing activity against AMS have attracted interest as screening targets for new odor-reducing agents.

In our screening programs to isolate active substances exhibiting deodorizing activity against AMS, we identified 1,8-cineole from cluster mallow leaves. Here, we focused upon 1,8-cineole and its isomer, 1,4-cineole, and investigated the deodorizing activity-related properties of these substances (Figure 1).

\section{Materials and Methods}

Chemicals. 1,8-Cineole (hereafter 1,8-C; purity: 99.8\%), 1,4-cineole (hereafter 1,4-C; purity: >95\%, SigmaAldrich, St. Louis, MO, USA), silica gel (Wakosil C-300), MM, and dimethyl trisulfide (DMTS) were purchased from Wako Pure Chemical Industries (Tokyo, Japan). Finely ground leaves of cluster mallow (Chinese herbal preparation) were obtained from Kahya Co., Ltd. (Osaka, Japan). 2-Nonenal and AMS were obtained from Alfa Aesar (Ward Hill, MA, USA); skatole, allyl mercaptan (AM), and dimethyl sulfide (DMS) were obtained from Acros Organics (Pittsburgh, PA, USA); indole and butyric acid were obtained from Kishida Chemical Co. (Osaka, Japan); and dimethyl disulfide (DMDS), isovaleric acid, and diacetyl were obtained from Tokyo Chemical Industry (Tokyo, Japan).

Preparation of screening samples. A variety of natural materials were purchased from local markets, including fruits (23 types), vegetables (18 types), seeds (12 types), teas/herbal plants (33 types), sea weeds (13 types), and mushrooms (10 types). The natural materials were initially lyophilized and processed by grinding using a mortar. Commercially dried and ground plant materials, such as a variety of teas/herbal plants, including leaves of cluster mallow, were also screened. A total of 109 samples were screened (Table 1).

To prepare screening samples, natural material prepared as described above (10 g) was weighed in a conical flask, to which $100 \mathrm{~mL}$ of $50 \%$ aqueous ethanol was then added and stirred for $30 \mathrm{~min}$ at room temperature using a magnetic mixer. The sample was then centrifuged for $10 \mathrm{~min}(1500 \mathrm{~g})$, and the supernatant was collected. The sample was re-extracted twice using the method described above. The ethanol was removed from the combined extract using a rotary evaporator. The final concentrated extract solutions were then lyophilized and powdered.

For gas chromatography (GC) analyses for screening, approximately $100 \mathrm{mg}$ of the sample suspended in $1 \mathrm{~mL}$ of deionized water was placed in a separate $300-\mathrm{mL}$ conical flask. A variety of phenolic compounds with deodorizing activity, such as catechins, have been isolated from plant extracts and identified to date. To minimize the possibility of isolating known phenolic compounds, we selected samples that gave negative results in a ferric chloride test (ferric chloride test: a few drops of $10 \%$ ferric chloride solution are added to the test sample solution; the formation of bluish-black color indicates the presence of phenolic compounds).

For specific analysis of the deodorizing activity against various odorous chemicals, cineole (a colorless liquid) was placed directly inside a 300-mL conical flask just below the neck using a micropipette (cineole volume: $110 \mu \mathrm{L}, 220 \mu \mathrm{L}$, or $330 \mu \mathrm{L}$ ), and $\mathrm{GC}$ analyses were conducted.

GC and gas detector tube analyses. Screening the natu- 
ral materials for deodorizing activity was performed via GC. In each assay, the sample was placed in a 300$\mathrm{mL}$ conical flask as described above, and then $10 \mu \mathrm{L}$ of AMS (or other odorous chemical) solution was injected into the flask through the Parafilm ${ }^{\circledR}$ covering the flask mouth using a microsyringe and the same method described above for cineole. The mouth of the flask was sealed tightly with Parafilm ${ }^{\circledR}$ again (double sealed) immediately after addition of the odorous chemical solution. The flask was left to stand for $60 \mathrm{~min}$ at $25^{\circ} \mathrm{C}$, and then $2 \mathrm{~mL}$ of the headspace gas was analyzed on a Shimadzu GC-2014AF GC apparatus. We assumed that the loss of odorous gases by permeation through the Parafilm and by adsorption onto the glass during 60 min of incubation at $25^{\circ} \mathrm{C}$ (deodorizing reaction completely or almost completely reached plateau values) was not significantly different between the sample flask and control flask. In the case of DMTS, the loss was $2.4 \%$ (average of three measurements). Details regarding GC conditions are shown in Table 2. The initial concentration of odorous chemical was $1 \mathrm{ppm}$ in the gas phase, with the following exceptions: for skatole, indole, isovaleric acid, and diacetyl, the initial concentration was $10 \mathrm{ppm}$, because the GC peaks for these gases at a concentration of $1 \mathrm{ppm}$ were too small under the GC conditions used to allow for quantification. We observed that the deodorizing activity of cineole was unaffected by the initial concentrations of odorous gases tested (Table 3).

Deodorizing activity, expressed as percent reduction in odorous gas concentration in the headspace, was calculated using the following formula: deodorizing activity $(\%)=(\mathrm{C}-\mathrm{S}) / \mathrm{C} \times 100$, where $\mathrm{C}$ represents the peak area for the authentic chemical standard in the headspace gas of the reaction mixture without a test sample (control), and S represents the peak area for the headspace gas of the reaction mixture containing the test sample ${ }^{4)}$.

An AP-20 Kitagawa Gas Detector Tube System was used to detect acetic acid, trimethylamine (TMA), acetaldehyde, and ammonia. A tube connected to an aspirating pump was inserted through a slit in the Parafilm covering the sample flask made using a knife, and a $100-\mathrm{mL}$ sample of the headspace gas was withdrawn and analyzed using the gas detector. The odorant concentration (ppm) was determined by direct reading from the scale on the tube. Deodorizing activi- ty (\%) was calculated using the formula described above for GC analyses. For gas detector analyses, the initial concentration of malodorous chemical was 10 ppm.

Solid-phase micro-extraction (SPME) and GC/MS conditions for determination of the active principle. A 2 -mg sample was placed in a 2 -mL screw-top vial. Collection of volatile compounds was accomplished using a 15 -min adsorption period at $60^{\circ} \mathrm{C}$, during which the sample was shaken. The SPME fiber introduced into the headspace of the sample vial was an $85-\mu \mathrm{m}$ layer of Carboxen/PDMS Stable Flex (Sigma-Aldrich Co.). After SPME, the compounds were analyzed using GC/MS. GC/MS was performed using a Hewlett Packard HP5890 Series II gas chromatograph coupled to a Hewlett Packard HP5872 series mass spectrometer. A DB-WAX capillary column $(60 \mathrm{~m} \times 0.25 \mathrm{~mm}$ i.d.; film thickness: $0.25 \mu \mathrm{m}$ ) was used for separation. Highpurity helium was used as the carrier gas at a flow rate of $1.2 \mathrm{~mL} / \mathrm{min}$. The column temperature was programmed to increase from $40^{\circ} \mathrm{C}$ (held for $4 \mathrm{~min}$ ) to $200^{\circ} \mathrm{C}$ at $4^{\circ} \mathrm{C} / \mathrm{min}$. The injection and detection temperatures were 260 and $220^{\circ} \mathrm{C}$, respectively. The ionization voltage was set at $70 \mathrm{eV}$. Chemical components were identified by comparing their mass spectra and retention times to those of commercially available library standards (NIST Chemistry WebBook).

Fractionation of cluster mallow leaf extract using silica gel column chromatography. The 50\% aqueous ethanol extract of finely ground leaves of cluster mallow was re-extracted and fractionated as follows. Lyophilized and powdered extract (200 g), prepared as described above, was suspended in water $(3.5 \mathrm{~L})$, stirred for $30 \mathrm{~min}$, and then divided into two portions by centrifugation: water soluble and insoluble. After the extraction procedure was repeated twice, $181.4 \mathrm{~g}$ of watersoluble material and $11.4 \mathrm{~g}$ of insoluble material were obtained. The water-insoluble material was soluble in $\mathrm{CHCl}_{3}$ and exhibited relatively stronger deodorizing activity compared with the soluble material and a negative ferric chloride test result, which indicated the absence of phenolic compounds such as catechins in the insoluble portion. The silica gel column (silica gel: $170 \mathrm{~mL}$ ) was prepared using a Komagome pipette with $\mathrm{CHCl}_{3}$. The column was $20 \mathrm{~cm}$ in length, with a $4-\mathrm{cm}$ internal diameter. The column was loaded with the $\mathrm{CHCl}_{3}$-soluble extract material $(8.9 \mathrm{~g})$ and eluted with 


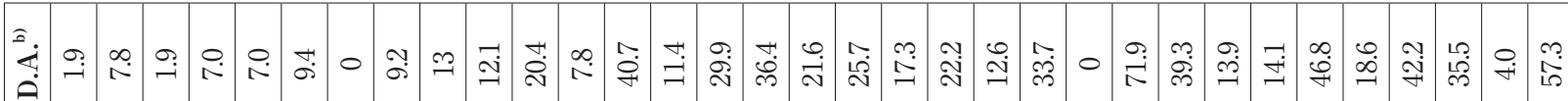

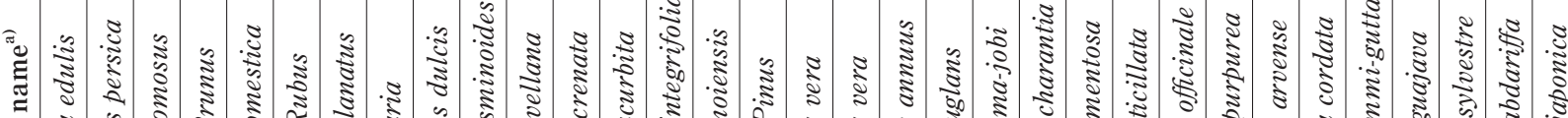

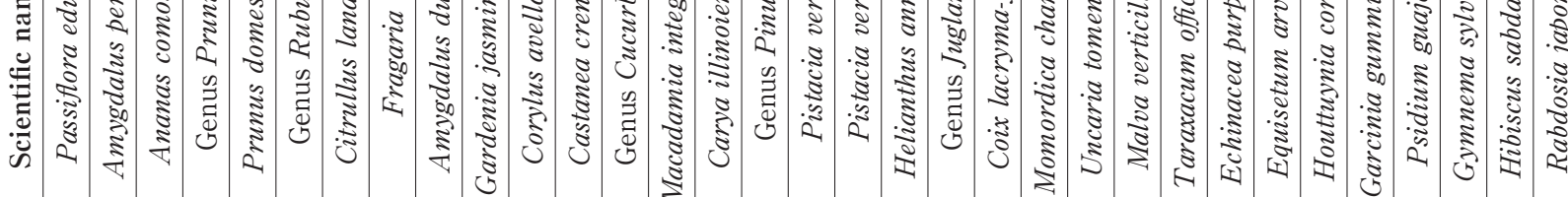

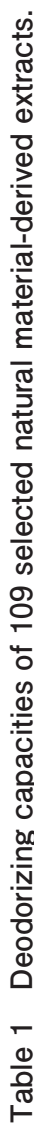

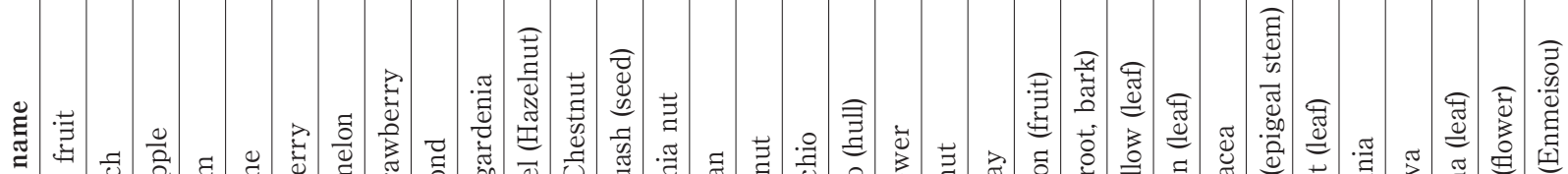

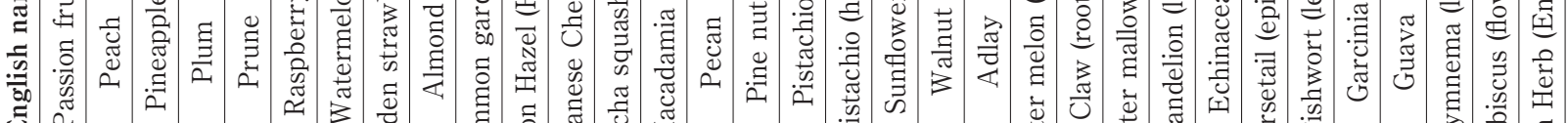

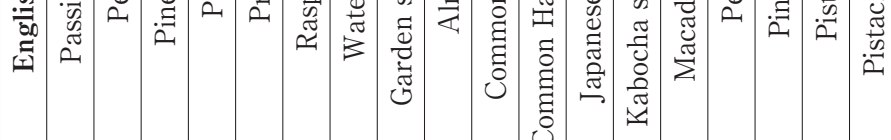

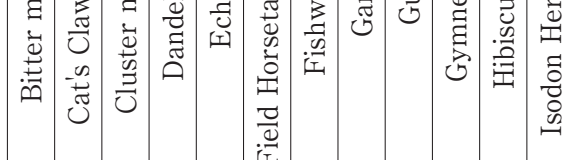

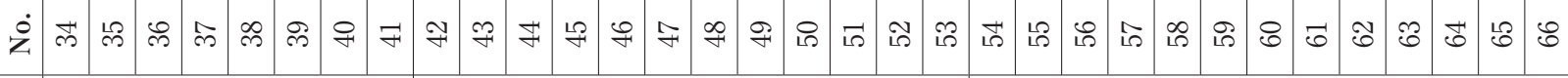
(pənụฺuoว) sł!̣n.xH spəəs

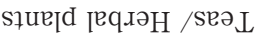

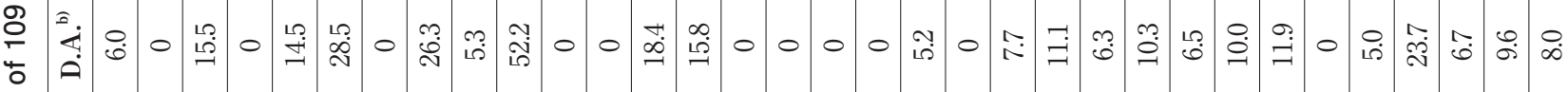

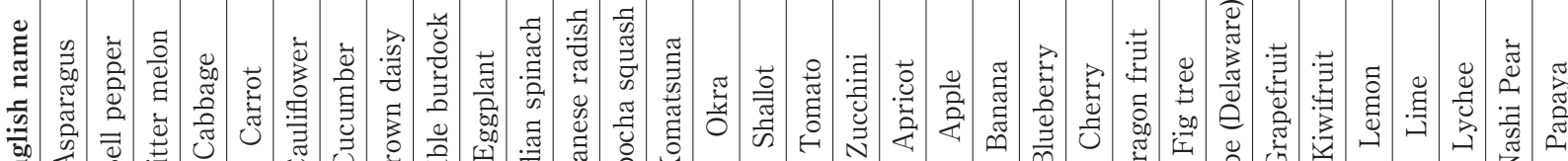
空

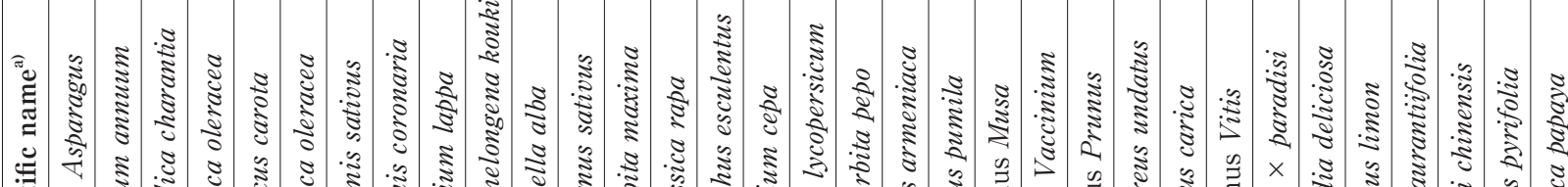

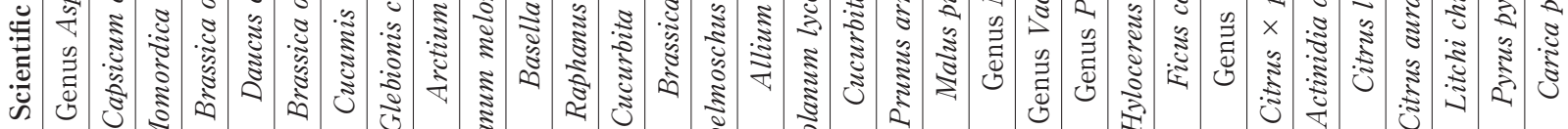

$\frac{0}{\frac{0}{0}}$

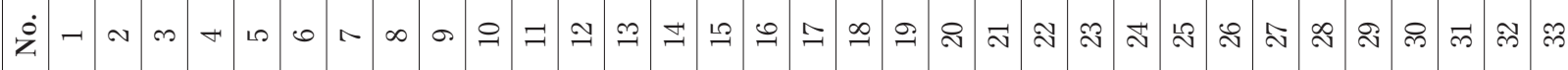




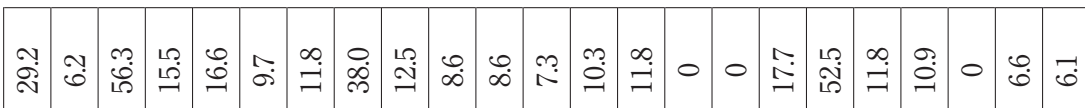

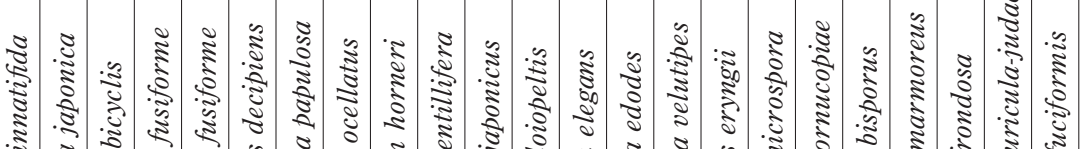

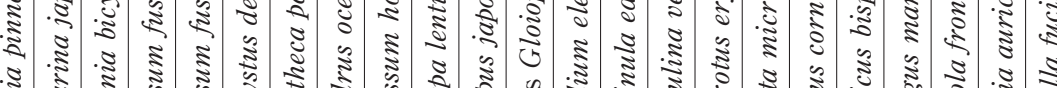

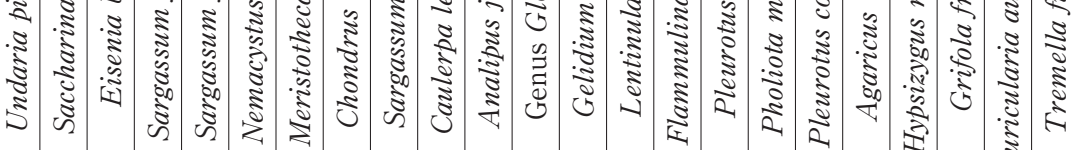

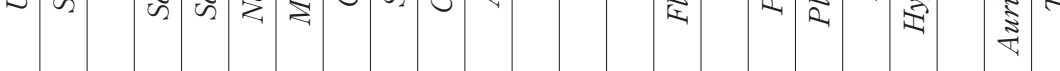

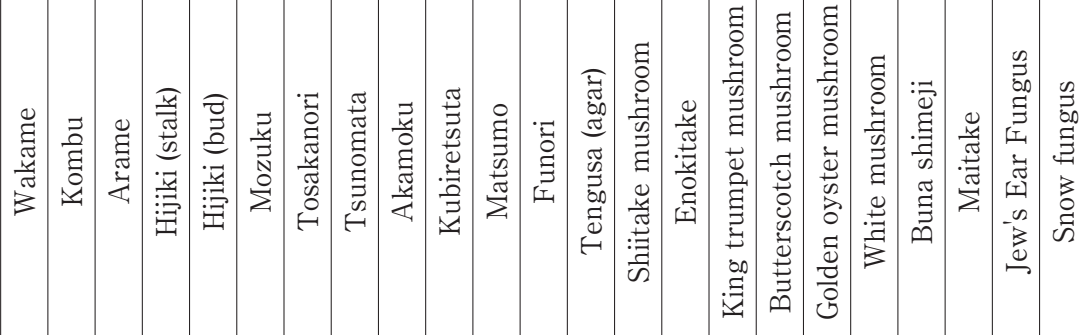

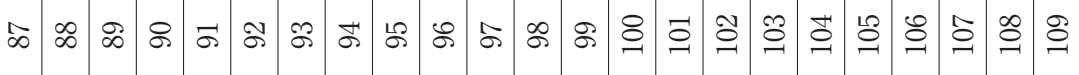

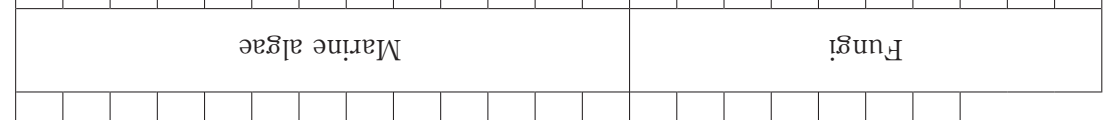

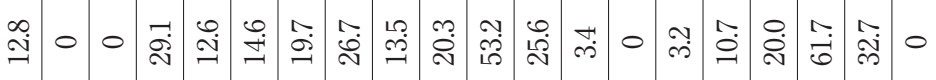

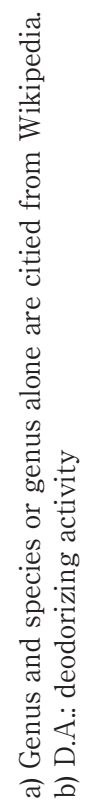

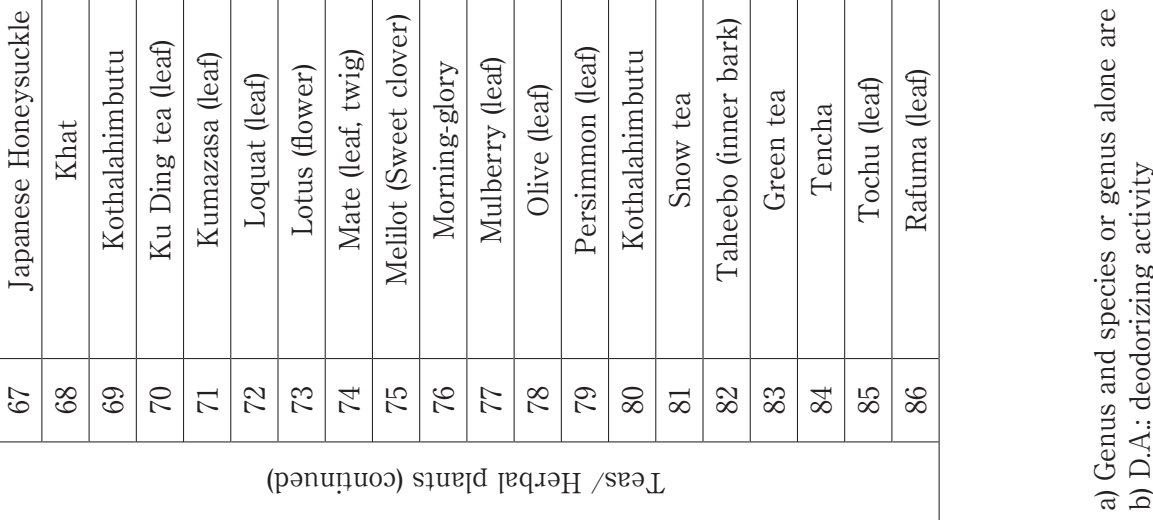


Table 2 Gas chromatography conditions.

\begin{tabular}{|c|c|c|c|c|c|}
\hline \multirow{2}{*}{ Malodorous gas } & \multirow{2}{*}{ Column } & \multirow{2}{*}{ Detector $^{\mathrm{b}}$} & \multicolumn{2}{|c|}{ Temperature $\left({ }^{\circ} \mathrm{C}\right)$} & \multirow{2}{*}{ Carrier gas flow rate } \\
\hline & & & injector & oven & \\
\hline DMDS, DMTS & $\begin{array}{l}\text { Unisole F-200 } \\
30 / 60\end{array}$ & FPD & 120 & 80 & 20 \\
\hline $\begin{array}{l}\text { MM, AM } \\
\text { AMS, DMS }\end{array}$ & $\begin{array}{l}\text { Unisole F-200 } \\
30 / 60\end{array}$ & FPD & 120 & 50 & 20 \\
\hline $\begin{array}{l}\text { Isovaleric acid } \\
\text { n-Butyric acid } \\
\text { 2-Nonenal }\end{array}$ & $\begin{array}{l}\text { Unisole F-200 } \\
30 / 60\end{array}$ & FPD & 200 & 120 & 50 \\
\hline Indole, Skatole & $\begin{array}{l}\text { OV-17 } \\
60 / 80\end{array}$ & FID & 200 & 120 & 50 \\
\hline Diacetyl & $\begin{array}{l}\text { Sunpak-A } \\
50 / 80\end{array}$ & FID & 230 & 180 & 50 \\
\hline
\end{tabular}

Notes: ${ }^{a}$ Nitrogen, $\mathrm{mL} / \mathrm{min}$; ${ }^{\mathrm{b}}$ Detector temperature, $200^{\circ} \mathrm{C}$.

Table 3 Deodorizing activity (\%) of 1,8-cineole against different initial concentrations of malodorous gases.

\begin{tabular}{ccccc}
\hline $\begin{array}{c}\text { Initial } \\
\text { concentration }(\mathrm{ppm})\end{array}$ & 1 & 10 & 50 & 100 \\
\hline DMTS & $91 \pm 0.5$ & $96 \pm 0.4$ & n.d. & $95 \pm 0.7$ \\
Isovaleric acid & n.d. & $91 \pm 1.9$ & $82 \pm 1.2$ & $86 \pm 2.6$ \\
Indole & n.d. & $91 \pm 0.7$ & $89 \pm 2.1$ & $94 \pm 1.3$ \\
Skatole & n.d. & $85 \pm 2.2$ & $94 \pm 0.5$ & $94 \pm 3.1$ \\
DMDS & n.d. & $91 \pm 1.9$ & $81 \pm 1.2$ & $86 \pm 2.6$ \\
\hline
\end{tabular}

Notes: Concentration of 1,8-cineole, $100 \mathrm{mg} / 300-\mathrm{mL}$ flask; n.d., not determined.

$\mathrm{CHCl}_{3}$. The fraction volume was $200 \mathrm{~mL}$, and a total of 20 fractions were collected. For analysis of the deodorizing activity of each fraction, $100 \mu \mathrm{L}$ of chloroform eluate from each fraction was added to a $300-\mathrm{mL}$ conical flask, and the chloroform was evaporated to dryness by incubation at room temperature.

Desorption analyses. Desorption experiments were conducted using a Shimadzu headspace sampler HS-20 and GCMS-TQ8040 system. A total of $50 \mathrm{mg}$ of 1,8-C and $100 \mathrm{ppm}$ of odorous gas, including 2-nonenal, DMTS, isovaleric acid, or skatole, was placed directly inside a 20-mL HS vial and incubated at $37^{\circ} \mathrm{C}$ for $1 \mathrm{~h}$. Under these conditions, $99.5-99.7 \%$ of each odorous gas was adsorbed to 1,8-C. The HS-20 vial containing 1,8-C with adsorbed odorous gas was left to stand for $60 \mathrm{~min}$ at $50,75,100$, or $150^{\circ} \mathrm{C}$, and then the desorbed gas was measured.

Organoleptic measurement (OM). OMs were performed as follows. A 300-mL conical flask containing
$50 \mathrm{mg}$ of cineole was incubated with a variety of odorous gases at $25^{\circ} \mathrm{C}$ for $60 \mathrm{~min}$. To prepare odorous gas solutions, 1:10 or 1:2 dilutions of original odorous solutions were prepared to give a range of concentrations appropriate for organoleptic measurements with a 3-4 malodor intensity level. The volume of odorous gas solution injected into the $300-\mathrm{mL}$ flask was $2-10 \mu \mathrm{L}$. The judges sniffed the odorant-containing air inside the odor flask directly after giving oral consent to participate in the study, which was conducted with reference to the "Olfactory Measurement Method Safety Management Manual," published by the Ministry of the Environment, Government of Japan.

\section{Results and Discussion}

Identification of the active principle in cluster mallow extract. In this study, we conducted a screening of extracts of a variety of natural materials in an attempt to identify new deodorizing compounds, using an 
Table 4 Deodorizing activity, initial concentration, molecular weight, boiling point, solubility, and generation source of odorous gases.

\begin{tabular}{|c|c|c|c|c|c|c|}
\hline $\begin{array}{l}\text { Malodorous } \\
\text { gas }\end{array}$ & $\begin{array}{l}\text { Deodorizing } \\
\text { activity }(\%)^{\mathrm{a}}\end{array}$ & $\begin{array}{l}\text { Initial conc. } \\
\qquad(\mathrm{ppm})\end{array}$ & $\mathrm{MW}^{\mathrm{b}}$ & $\begin{array}{l}\text { Boiling point } \\
\left({ }^{\circ} \mathrm{C}\right)\end{array}$ & $\begin{array}{l}\text { Solubility } \\
\text { in water }\end{array}$ & $\begin{array}{c}\text { Generation source } \\
\text { (example) }\end{array}$ \\
\hline 2-Nonenal & $95.6 \pm 0.6$ & 1 & 140.22 & $88-90$ & $-{ }^{d}$ & Body (over middle aged) \\
\hline Skatole & $92.7 \pm 1.7$ & 10 & 131.17 & 265 & $-{ }^{d}$ & feces \\
\hline DMTS & $97.3 \pm 0.5$ & 1 & 126.27 & 170 & $\pm^{e}$ & cancer wound \\
\hline Indole & $94.3 \pm 0.5$ & 10 & 117.15 & 253 & $\pm^{e}$ & feces \\
\hline Isovaleric acid & $97.0 \pm 1.0$ & 10 & 102.13 & 176 & $\pm^{e}$ & sole of foot \\
\hline DMDS & $94.6 \pm 0.4$ & 1 & 94.19 & 110 & $\pm^{e}$ & garlic breath \\
\hline AMS & $88.0 \pm 4.7$ & 1 & 88.17 & 92 & $\pm^{e}$ & garlic breath \\
\hline n-Butyric acid & $74.5 \pm 7.6$ & 1 & 88.11 & 163 & $\pm^{e}$ & sole of foot \\
\hline Diacetyl & $40.8 \pm 0.2$ & 10 & 86.09 & 88 & $+{ }^{\mathrm{f}}$ & axillae, foot, head \\
\hline $\mathrm{AM}$ & $72.4 \pm 5.4$ & 1 & 74.14 & $67-68$ & $-{ }^{d}$ & garlic breath \\
\hline DMS & $76.8 \pm 0.7$ & 1 & 62.13 & 37.3 & $\pm^{e}$ & rotten meat \\
\hline $\mathrm{MM}$ & $69.1 \pm 0.7$ & 1 & 48.11 & 5.95 & $\pm^{\mathrm{e}}$ & garlic breath \\
\hline Acetic acid $^{c}$ & $17.0^{\mathrm{h}}$ & 10 & 60.05 & 110 & $++^{g}$ & kitchen garbage \\
\hline $\mathrm{TMA}^{\mathrm{c}}$ & $0^{\mathrm{h}}$ & 10 & 59.11 & 2.9 & $++^{g}$ & rotten fish \\
\hline Acetaldehyde $^{c}$ & $0^{\mathrm{h}}$ & 10 & 44.05 & 20 & $++^{g}$ & cigarette smoke \\
\hline Ammonia $^{c}$ & $0^{\mathrm{h}}$ & 10 & 17.03 & -33.3 & $++^{g}$ & livestock waste \\
\hline
\end{tabular}

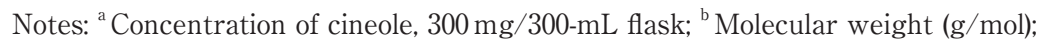

${ }^{\mathrm{c}}$ Deodorizing activity was measured using a gas detector tube system;

${ }^{\mathrm{d}}$ Insoluble; ${ }^{\mathrm{e}}$ Slightly soluble; ${ }^{\mathrm{f}}$ Soluble; ${ }^{\mathrm{g}}$ Very soluble;

${ }^{\mathrm{h}}$ Values are expressed as the mean of two independent assays.

AMS-targeted GC-based approach. Table 1 summarizes the results of our screening of 109 natural materialderived extracts. Among the samples screened, there was a relatively high rate of detection in the tea/herbal plant category and seed category, and cluster mallow leaves exhibited the highest deodorizing activity. The second highest activity against AMS was detected in a Tencha extract, for which deodorizing activity was reported by Shimizu et al. ${ }^{8}$.

Cluster mallow leaves are a good candidate source of compounds for use in deodorant products, exhibiting a deodorizing activity of $70 \%$. The candidate sample was subjected to silica gel column chromatography. Analysis of the water-insoluble/ $\mathrm{CHCl}_{3}$-soluble sample yielded 20 fractions, with peaks exhibiting deodorizing activity against AMS present in fractions 6-9 (a broad peak) and 17. Fractions 6-9 (containing $730 \mathrm{mg}$ of active principle) were combined, and the active principle was further purified by an additional round of chromatography on the same column and following repeated preparative TLC. Based on LC/MS/MS and UV-Vis spectroscopy analyses, the active principle was deduced to be pheophorbide-a (data not shown). As authentic pheophorbide-a exhibited strong deodorizing activity against AMS (to the best of our knowledge, strong deodorizing activity of pheophorbide-a has not been reported to date; thus, a detailed study will be reported elsewhere), the compound is an interesting candidate odor-reducing agent. However, as pheophorbide-a is reportedly toxic to rats ${ }^{9)}$, we did not investigate this compound further.

The chemical constituents of fraction $17(80 \mathrm{mg})$ were analyzed by $\mathrm{GC} / \mathrm{MS}$, which revealed that 80 components were present (data not shown). Six major components identified by GC/MS analysis included 1,8-C, 2-nonenal, acetic acid, 2-ethyl-1-hexanol, hexanoic acid, and 2-amino-4-methoxyphenol, each of which individually constituted greater than $2 \%$ of the total GC peak area and together constituted $30.8 \%$ of the total peak area. These compounds were chosen for further analysis. Of the 6 selected compounds, 2-nonenal and acetic acid are typical malodors experienced in daily life. On the other hand, 2-ethyl-1-hexanol, hexanoic acid, and 2-amino-4-methoxyphenol, while less common, are also strongly pungent compounds, in which we are not interested. Furthermore, these 3 compounds exhibited weak deodorizing activities of $18.3 \%, 0.7 \%$, and $7.7 \%$, respectively, for $300 \mathrm{mg} / 300-\mathrm{mL}$ flask. The last compound, 1,8-C, exhibited potent deodorizing activity against AMS, which was our screening target $88 \%$ for 
Table 5 Six major compounds identified by SPME/GC/MS analysis of fraction 17.

\begin{tabular}{l|c|c}
\hline \multicolumn{1}{c|}{ Identified compound } & Retention time (min) & GC peak area (\%) \\
\hline 1,8-Cineole & 19.0 & 13.2 \\
2-Nonenal & 24.8 & 6.6 \\
Acetic acid & 26.2 & 3.8 \\
2-Ethyl-1-hexanol & 27.5 & 2.7 \\
Hexanoic acid & 36.7 & 2.3 \\
2-Amino-4-methoxyphenol & 46.9 & 2.2 \\
\hline \multicolumn{2}{c}{ Total peak area } \\
\hline
\end{tabular}

Note: The SPME contaminant, hexamethyl cyclotrisiloxane $(6.4 \%$; deodorizing activity: zero) was observed

$300 \mathrm{mg}$ of 1,8-C/300-mL flask, Table 4, Table 5). Thus, we concluded that $1,8-\mathrm{C}$ was the deodorizing active principle in fraction 17.

1,8-C, also known as eucalyptol, is a liquid terpene present in many plants, particularly Eucalyptus species ${ }^{10)}$, and was not included among our 109 screening materials. 1,8-C exhibits a camphor-like odor and is known for its ability to mask offensive odors by its fragrant aroma. We report here for the first time that 1,8-C deodorizes offensive malodors not only by masking them but also by reducing the concentration of odorous gases (Japan Patent 6342382) ${ }^{11)}$. We will discuss the physical mechanism of deodorization in more detail later. Among essential oil components, 1,8-C is generally more useful, as it is easily extractable on a commercial scale. 1,4-C, which is also used as a flavoring and fragrance compound, is found in red wines ${ }^{12)}$ and plant essential oils ${ }^{13)}$. We examined the deodorizing activity of both terpenes using commercially available authentic reagents.

Deodorizing activity of cineole against various malodorous gases in vitro. We investigated the deodorizing effect of cineole on a variety of odorous gases, such as those associated with garlic breath, animal waste, cigarette smoke, and rotten meat (Table 4). The deodorizing activity of 1,4-C and 1,8-C was tested against a total of 12 odorous gases using GC.

The review by Iwasaki indicated that the human olfactory sense is generally capable of clearly discriminating differences in odor intensity when there is a 10fold difference between two odor concentrations and can recognize as little as a 3-fold difference in odor concentration $^{14)}$. As such, it is preferable for newly developed deodorant products to exhibit deodorizing activity of approximately $90 \%$ against odorous gases. We determined the concentration of cineole necessary to capture $>80 \%$ of AMS in a $300-\mathrm{mL}$ flask. We also investigated the dose dependence of cineole on deodorizing activity at three doses, 100,200 , and $300 \mathrm{mg} / 300$ $\mathrm{mL}$ flask.

In our assay system, 1,8-C exhibited strong deodorizing activity (94-97\% for $300 \mathrm{mg}$ of $1,8-\mathrm{C} / 300-\mathrm{mL}$ flask) against 2-nonenal, skatole, DMTS, indole, isovaleric acid, and DMDS and moderate deodorizing activity (69-88\%) against AMS, n-butyric acid, AM, DMS, and MM. In contrast, 1,8-C exhibited only weak deodorizing activity against diacetyl (Fig. 2A, Table 4).

Compared with 1,8-C, 1,4-C exhibited slightly weaker deodorizing activity, especially against MM and DMS (Fig. 2B). It is possible that differences in hydrophobicity (water solubility: 1,8-C, $0.022 \mathrm{~g} / \mathrm{L}$ and 1,4-C, $0.058 \mathrm{~g} / \mathrm{L}$ ) and boiling point $\left(1,8-\mathrm{C}, 176.5^{\circ} \mathrm{C} ; 1,4-\mathrm{C}, 173.5^{\circ} \mathrm{C}\right)$ between 1,8-C and 1,4-C could be responsible for the difference in deodorizing activity. However, whether such moderate differences in physicochemical properties could produce the observed differences in deodorizing activity is unclear. We will discuss the influence of boiling point on deodorizing activity later. Both 1,4- and 1,8-C exhibited dose-dependent deodorizing activity against the odorous gases examined.

The deodorizing activity of 1,8-C against 2-nonenal was investigated in more detail. The activity decreased markedly at a concentration of $<50 \mathrm{mg} / 300-\mathrm{mL}$ flask. The relationship between deodorizing activity and 1,8$\mathrm{C}$ concentration was sigmoidal rather than linear (data not shown).

Table 3 shows that 1,8-C exerts a constant deodorizing effect against a variety of gases over a wide range 

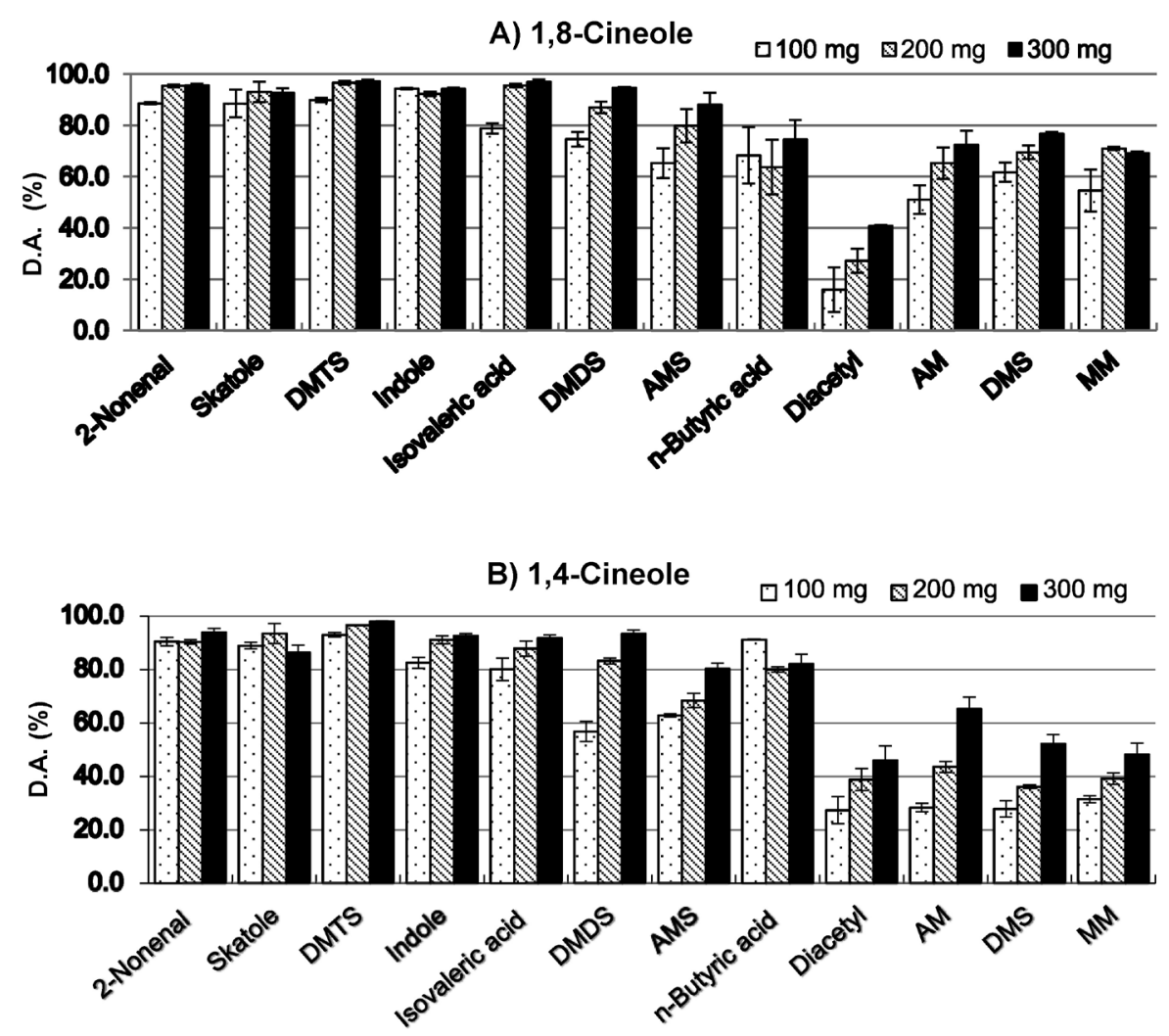

Fig. 2 Deodorizing activity of A) 1,8-C and B) 1,4-C against a variety of odorous gases.

Notes: Deodorizing activity was measured at three different concentrations, as described in the "Materials and Methods." Data represent the mean \pm standard deviation of three independent experiments.

DMTS, dimethyl trisulfide; DMDS, dimethyl disulfide; AMS, allyl methyl sulfide; AM, allyl mercaptan; DMS, dimethyl sulfide; MM, methyl mercaptan.

D.A.: Deodorizing activity.

of concentrations, from 1 to $100 \mathrm{ppm}$. This means that deodorant products containing 1,8-C could be used to treat ambient malodors exhibiting a wide odor intensity range.

Organoleptic assessment of cineole on various odorous gases. The changes in mean organoleptic scores for the head space of flasks containing 1,8-C incubated with various odorous gases at $25^{\circ} \mathrm{C}$ for $1 \mathrm{~h}$ are shown in Table 6. The organoleptic score was determined by two trained judges who had a national deodorization navigator license. The judges rated the characteristic odor (e.g., greasy or grassy smell for 2-nonenal) of each odorous gas with a score of 0 to 5 , where 0 represented the absence of odor, 1 barely noticeable odor, 2 slight malodor, 3 moderate malodor, 4 strong malodor, and 5 severe malodor. The mean odor score was used as the representative score. 1,8-C reduced the organoleptic scores of 2-nonenal, skatole, DMTS, AMS, n-butyric acid, isovaleric acid, and DMDS by more than 2 units.

Greenman et al. investigated the relationship between organoleptic score and the concentrations of pure odor- ous gases likely responsible for human oral malodor ${ }^{15)}$. Various concentrations of odorous gases that are constituents of oral malodor were subjectively scored by trained odor judges based on intensity level as 0 (below threshold) to 5 (extremely strong). The authors showed that the organoleptic score was proportional to the log concentration of pure odorous gas. Furthermore, they calculated values indicating the level of increase in gas concentration required to increase the organoleptic score by 1 unit. These values were a 10 -fold increase for n-butyric acid and DMDS (in this case, reduction to one-tenth is equivalent to a deodorizing activity of 90\%), 42-fold increase for isovaleric acid (deodorizing activity: 97\%), 8-fold increase for skatole (deodorizing activity: 87\%), and 7.2-fold increase for MM (deodorizing activity: $86 \%$ ). These data show that deodorizing activities stronger than approximately $90 \%$ produce more than a 1-unit reduction in organoleptic score.

A comparison of the organoleptic score data shown in Table 6 with data from Greenman et al. revealed that the reductions in organoleptic scores in this study 
Table 6 Changes in organoleptic measurement (OM) score. ${ }^{a}$

\begin{tabular}{|c|c|c|c|c|c|}
\hline Odorous gas & $\begin{array}{c}\text { Without } \\
\text { incubation }^{\mathrm{b}}\end{array}$ & $\begin{array}{c}\text { With } \\
\text { incubation }^{c}\end{array}$ & $\begin{array}{c}\text { Reduction of } \\
\text { OM score }\end{array}$ & $\begin{array}{l}\text { Deodorizing } \\
\text { activity }(\%)^{\mathrm{d}}\end{array}$ & $\begin{array}{c}\text { Deodorizing } \\
\text { activity (\%) } \\
\text { (Greenman et al.) }\end{array}$ \\
\hline 2-Nonenal & 3 & 0 & 3 & 96 & - \\
\hline Skatole & 3.5 & 0.5 & 3.0 & 93 & 87 \\
\hline DMTS & 3 & 0 & 3 & 97 & - \\
\hline AMS & 3 & 1.5 & 1.5 & 88 & - \\
\hline n-Butyric acid & 3 & 1 & 2 & 75 & 90 \\
\hline Isovaleric acid & 3 & 1 & 2 & 97 & 97 \\
\hline Dimethyl disulfide & 3 & 0 & 3 & 95 & 90 \\
\hline
\end{tabular}

Notes: ${ }^{\text {a }}$ Scores are expressed as the mean of two independent assays conducted by two trained judges.

${ }^{\mathrm{b}}$ Odorant was incubated at $25^{\circ} \mathrm{C}$ for 60 min without $1,8-\mathrm{C}$.

${ }^{\mathrm{c}}$ Odorant was incubated at $25^{\circ} \mathrm{C}$ for $60 \mathrm{~min}$ with 1,8 -C.

${ }^{\mathrm{d}}$ Excerpted from Table 4.

${ }^{\mathrm{e}}$ Deodorizing activity required to decrease OM score by 1 unit. Adapted from Greenman et al. data (reference 15).

were more than 1 unit greater than those reported by Greenman et al. The effect of odor-masking fragrances reportedly involves different mechanisms. Osada et al. reported that citrus odorants such as citronellal can mask the odor of DMDS via a mechanism other than overwhelming the malodor ${ }^{16)}$. This suggests that in addition to reducing the odorous gas concentration, a masking activity of 1,8-C contributes in part to its deodorizing effect.

Fungating wounds sometimes occur in patients with advanced cancer. One of the physical symptoms of a fungating wound is malodor caused by bacteria. The primary odorant emanating from fungating wounds of advanced cancer patients was recently identified as $\operatorname{DMTS}^{17}$.

A popular conception holds that middle-aged persons have a particularly unpleasant odor known as "aging odor", which is described as an unpleasant greasy or grassy odor emitted from some individuals 40 years of age or older ${ }^{18)}$. As is the case of aging odor, microorganisms residing on the skin play an important role in the formation of human body odors, including foot odor. Short-chain fatty acids such as isovaleric acid and butyric acid are believed to be the major contributors to foot odor ${ }^{19}$. The potent deodorizing activity of 1,8-C against DMTS, 2-neonal, and isovaleric acid suggests that it could be used in products designed to eliminate or reduce these microorganism-associated body malodors.

Possible mechanism of the deodorizing activity of cineole. The general structures of the malodorous com- pounds deodorized by 1,8-C are quite different. For example, DMTS, DMDS, AMS, AM, DMS, and MM are sulfur-containing compounds, whereas 2-nonenal is an unsaturated aldehyde, isovaleric acid and n-butyric acid are fatty acids, and skatole and indole are aromatic heterocyclic compounds. However, like cineole, which is a cyclic ether and monoterpenoid, all of these compounds are hydrophobic. As shown in Table 4, 2-nonenal, skatole, and AM are insoluble in water, whereas DMTS, DMDS, AMS, DMS, MM, indole, isovaleric acid, and n-butyric acid are slightly soluble in water (solubility: $0.19-6 \mathrm{~g} / 100 \mathrm{~mL}$ ), and diacetyl is water soluble (solubility: $20 \mathrm{~g} / 100 \mathrm{~mL}$ ).

Negishi et al. proposed a possible mechanism for the deodorizing effects of foods, including lipids, against diallyl disulfide and diallyl sulfide ${ }^{6}$. The mechanism involves affinity-based physical and chemical interactions between these sulfur-containing compounds and specific food ingredients, each of which has hydrophobic properties.

In another study screening for deodorant compounds, we identified two hydrophobic compounds from plants. One was a high-molecular-weight, nonpolar lipid triolein (MW: $885.4 \mathrm{~g} / \mathrm{mol}$ ), and the other was a low-molecular-weight oleic acid (MW: $282.5 \mathrm{~g} /$ mol), both of which exhibited potent deodorizing activity against hydrophobic odorous gases (data not shown). This suggests that both high- and low-molecularweight hydrophobic compounds exhibit deodorizing activity against hydrophobic gases. Taking the above into account, this suggests that 1,8-C, a low-molecular- 


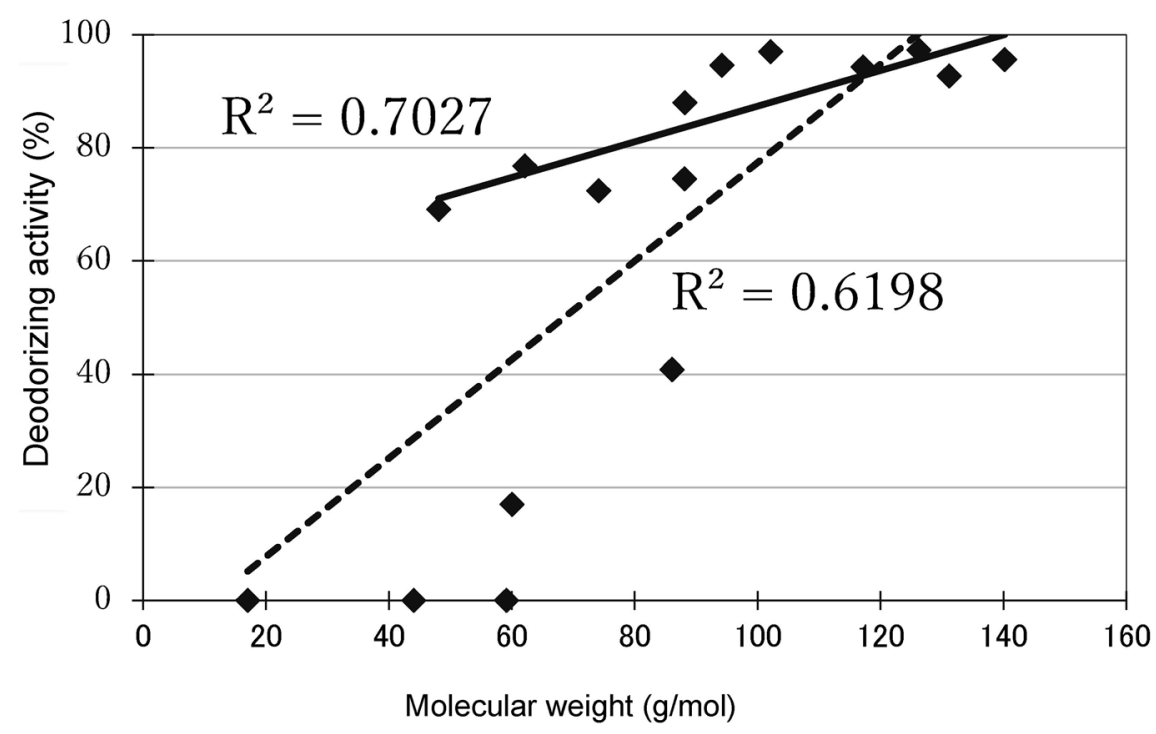

Fig. 3 Deodorizing activity of 1,8-cineole as a function of the molecular weight of the odorous gases shown in Table 4.

- Hydrophobic odorous gases shown in Table 4

- - - All odorous gases shown in Table 4

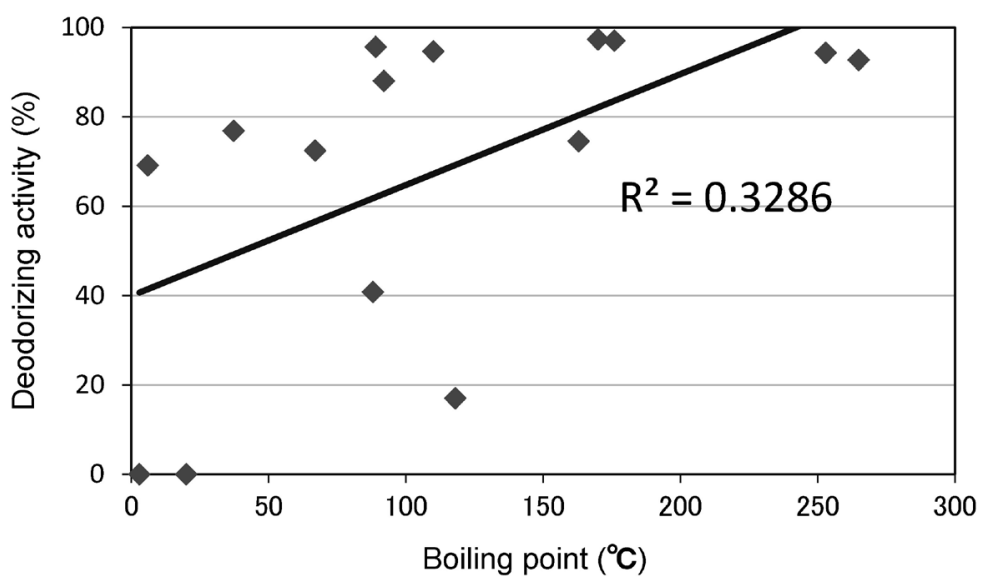

Fig. 4 Deodorizing activity of 1,8-cineole as a function of the boiling point of the odorous gases shown in Table 4.

weight compound (MW: $154.3 \mathrm{~g} / \mathrm{mol}$ ), interacts with hydrophobic odor molecules to draw them together, forming hydrophobic aggregates and thus reducing the intensity of the odor released.

In order to test this hypothesis further, the deodorizing activity of 1,8-C against hydrophilic odorants such as acetic acid, acetaldehyde, TMA, and ammonia was examined. As these odorous compounds could not be easily quantified by GC in the present study, we used a gas detector tube system. We found that 1,8-C exhibited no or weak deodorizing activity against hydrophilic odorants, including acetic acid, acetaldehyde, TMA, and ammonia (solubility: $144 \mathrm{~g} / 100 \mathrm{~mL}$ to infinite, deodorizing activity: 0 to $17 \%$ at $300 \mathrm{mg} / 300-\mathrm{mL}$ flask, Table 4). From this observation, it is clear that 1,8-C does not physically interact with hydrophilic odorants. This observation supports the hypothesis that the deodorizing mechanism of cineole involves hydrophobic interactions between the cineole and odorant molecules.

As shown in Table 4, the solubility of diacetyl in water is much higher than that of the slightly soluble compounds but much lower than that of the highly soluble compounds. It is interesting to note that diacetyl exhibited much less potent deodorizing activity than the other insoluble or slightly soluble compounds. 


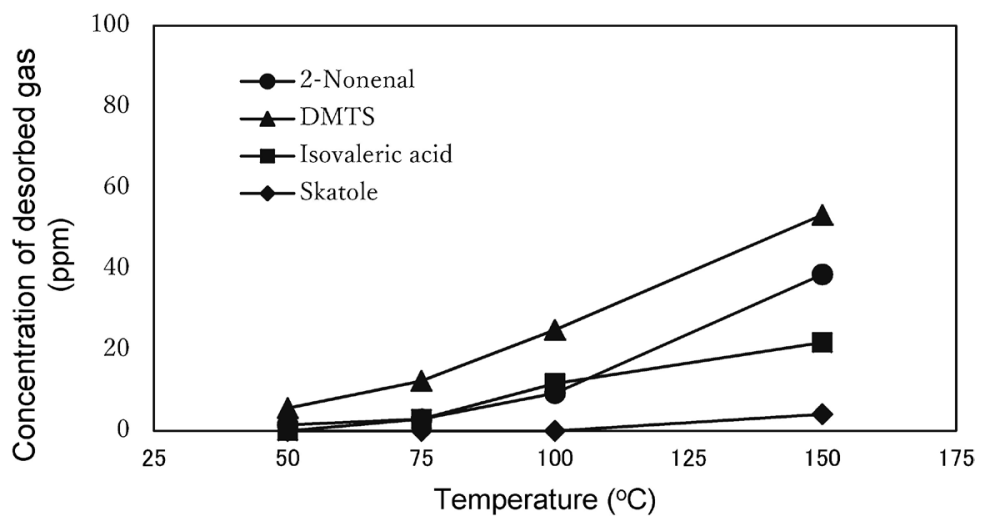

Fig 5 Effect of temperature on desorption of odorous gases.

Note: Desorption experiments were conducted as described in the "Materials and Methods."

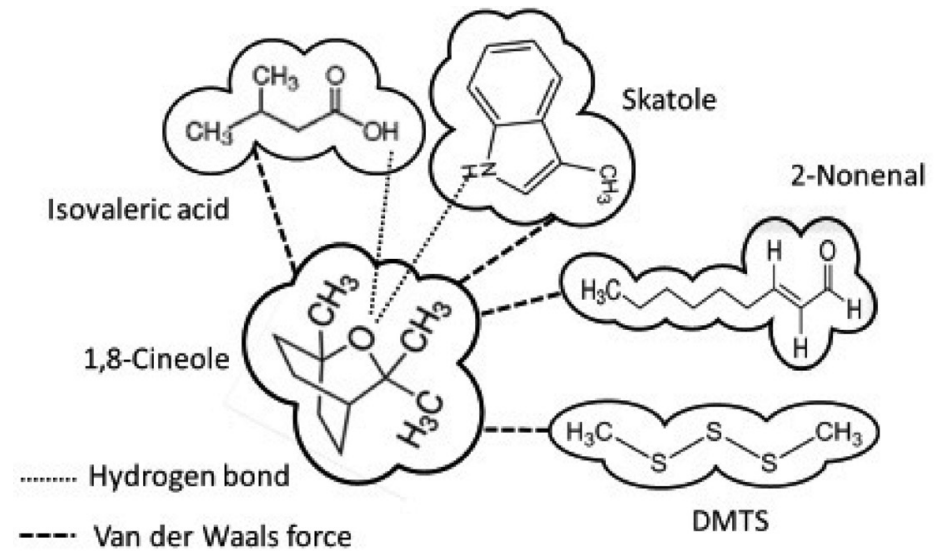

1,8-Cineole exhibits a deodorizing effect not only by masking odors but also through physical interactions such as van der Waals forces and/or hydrogen bonding between 1,8-cineole and odorants.

Fig. 6 Physical interaction between 1.8-cineole and odorous gases.

The relatively poorer deodorizing activity of diacetyl may thus be due to its intermediate hydrophobicity.

It is well known that adsorption of a water insoluble adsorbate to an adsorbent such as activated carbon occurs primarily via hydrophobic interactions, which are based on van der Waals forces between the adsorbate and adsorbent ${ }^{20,21)}$. Adsorption via van der Waals forces is reportedly affected by molecular properties such as hydrophobicity as well as a variety of other factors, including molecular weight and boiling point. In general, the greater the molecular weight, the stronger the van der Waals forces between the adsorbate and adsorbent, and consequently, the greater the extent of adsorption ${ }^{21,22)}$, which will, in turn, produce a stronger deodorizing effect.

We found a correlation between the deodorizing ac- tivity of 1,8-C and the molecular weight of the odorous gases tested. 1,8-C tended to deodorize high-molecularweight ( $>90 \mathrm{~g} / \mathrm{mol}$ ) odorous gases more effectively than low-molecular-weight ( $<90 \mathrm{~g} / \mathrm{mol})$ gases (Table 4). The coefficient of determination $\left(\mathrm{R}^{2}\right)^{23)}$ between the deodorizing activity of 1,8-C against the odorous gases shown in Table 4 and their molecular weight was high, at 0.6198. When considering only hydrophobic gases, the coefficient of determination was very high, at 0.7027 (Fig. 3). These correlation data suggest that the deodorizing mechanism of cineole is, at least in part, due to adsorption involving van der Waals forces.

It is also known that van der Waals forces are affected by the boiling point of adsorbates ${ }^{22), 24,25)}$. The higher the boiling point, the stronger the van der Waals forces. We found a correlation between the deodorizing 
activity of 1,8-C and the boiling point of the odorous gases tested (Fig. 4), although there were several exceptions, including 2-nonenal. The coefficient of determination $\left(\mathrm{R}^{2}\right)$ between the deodorizing activity of 1,8-C against the odorous gases and boiling points of the gases was 0.3286 , indicating a moderate correlation.

The van der Waals forces between 1,8-C and 2nonenal may be governed by the combined effects of their molecular properties. The number of carbons on hydrophobic molecules is important because the greater the number of carbons, the stronger the hydrophobic interaction. Linear carbon chain molecules can produce stronger hydrophobic interactions than branched molecules, because carbon branches produce steric hindrance. The fact that 2-nonenal has a long thin structure may explain its stronger deodorizing activity, although the boiling point of 2 -nonenal is not higher than that of the other high-molecular-weight gases testled (Table 4).

As van der Waals forces are relatively weak, physical adsorption is a readily reversible phenomenon. Because of their hydrophobicity, by raising the temperature, adsorbed hydrophobic gas molecules would be desorbed from 1,8-C, similar to the case of thermal desorption of an adsorbate from activated carbon surfaces $^{24), 26)}$. In view of the temperature dependence of adsorbate desorption, a desorption experiment was conducted at $50,75,100$, and $150^{\circ} \mathrm{C}$ at a constant $1,8-\mathrm{C}$ dose of $50 \mathrm{mg} / 35-\mathrm{mL}$ vial. The effect of temperature on the desorption of gases (including DMTS, 2-nonenal, isovaleric acid, and skatole) from 1,8-C is shown in Figure 5. The desorption of gases from 1,8-C was proportional to the incubation temperature. DMTS and 2-nonenal reached $53.3 \mathrm{ppm}$ and $38.6 \mathrm{ppm}$ at $150^{\circ} \mathrm{C}$, respectively, suggesting that the adsorption process involves a physical mechanism associated with van der Waals forces. The desorbed concentrations of isovaleric acid and skatole (21.8 ppm and $4.1 \mathrm{ppm}$, respectively) were lower than those of 2-nonenal and DMTS.

Deodorization of isovaleric acid and skatole could involve additional mechanisms. In addition to van der Waals forces, hydrogen bonding is another type of force in physical adsorption ${ }^{20), 21)}$. Isovaleric acid and skatole could form hydrogen bonds with the oxygen atom in 1,8-C (Fig. 6). From the above, the lower level of thermal desorption could be due to the formation of hydrogen bonds between those gases and 1,8-C. Addi- tional investigations, such as adsorption isotherm measurements, may be necessary to clarify the adsorption mechanism of 1,8-C in more detail.

\section{Concluding remarks}

The aim of this work was to discover novel natural products exhibiting deodorizing activity from natural material extracts. The screening target was AMS, which is a major component of garlic breath, and 1,8-C was identified from cluster mallow leaves as active against AMS. 1,8-C exhibited potent deodorizing activity against not only AMS but also other odorous gases that are components of diet- and disease-associated malodors, such as foot odor, aging-associated odor, and malodors emitted from fungating cancer wounds and feces. Our data indicate that 1,8-C could be a particularly useful odor-reducing agent. The possible deodorizing mechanism of cineole is suggested to involve van der Waals forces, and to a lesser extent, hydrogen bonding.

\section{Acknowledgement}

Our interest in the topic of hydrophobic interactions between cineole and odorous molecules was inspired and complemented by communications with Zenzaburo Tozuka (Osaka University).

Key words : cineole, malodor, deodorizing activity, hydrophobic interaction

Abbreviations: GC, gas chromatography; MS, mass spectrometry; DMTS, dimethyl trisulfide; DMDS, dimethyl disulfide; AMS, allyl methyl sulfide; DMS, dimethyl sulfide; AM, allyl mercaptan; MM, methyl mercaptan; TMA, trimethylamine, SPME, solid-phase micro-extraction.

\section{References}

1 ) Rappert S and Müller R.: Odor compounds in waste gas emissions from agricultural operations and food industries. Waste Manag., 25, 887-907, (2005).

2 ) Lodhia P, Yaegaki K, Khakbaznejad A, Imai T, Sato T, Tanaka T, Murata T, and Kamoda T.: Effect of green tea on volatile sulfur compounds in mouth air, J. Nutr. Sci. Vitaminol., 54, 89-94, (2008).

3 ) Mimasu T and Torii K.: U.S. Patent 4,681,757.

4 ) Yasuda H and Arakawa T.: Deodorizing mechanism of (-)-epigallocatechin gallate against methyl mercaptan, Biosci. Biotechnol. Biochem., 59, 1232-1236, (1995). 
5 ) Kida K, Suzuki M, Takagaki A, and Nanjo F.: Deodorizing effects of tea catechins on amines and ammonia, Biosci. Biotechnol. Biochem., 66, 373-377, (2002).

6 ) Negishi O, Negishi Y, and Ozawa T.: J. Agric. Food Chem., 50, 3856-3861, (2002).

7 ) Munch R and Barringer SA.: Deodorization of garlic breath volatiles by food and food components, J. Food Sci., 79, C526-C533, (2014).

8 ) Shimizu K, Maeda Y, Osawa K and Shimura S.: Deodorizing effect of Rubus suavissimus extract against allyl methyl sulfide, Nippon Shokuhin Kagaku Kaishi., 51, 205-209, (2004).

9 ) Matsuura E, Saito Y, Ishida H, Seki Y, Miki K, Fukimbara T, Kawahara H, and Ito H.: Toxic effects and changes of blood components by photodynamic action induced by pheophorbide-a in rats, Food Hygiene and Safety Science (Shokuhin Eiseigaku Zasshi), 23, 365-372, (1982).

10) Betts TJ.: Solid phase microextraction of volatile constituents from individual fresh Eucalyptus leaves of three species, Planta Med., 66, 193-195, (2000).

11) Henmi A, Sugino T, Nakamura $K$ and Okuhara M.: (2018) JP6342382

12) Antalick G, Tempère S, Šuklje K, Blackman JW, Deloire A, de Revel G, and Schmidtke LM.: Investigation and sensory characterization of 1,4-cineole: A potential aromatic maker of Australian cabernet sauvignon wine, $J$. Agric. Food Chem., 63, 9103-9111, (2015).

13) Romagni JG, Allen ST, and Dayan FE.: Allelopathic effects of volatile cineoles on two weedy plant species, $J$. Chem. Ecol., 26, 303-313, (2000).

14) Iwasaki Y.: Background of development of triangle odor bag method, J. Japan Association on Odor Environment, 43, 395-400, (2012).

15) Greenman J, El-Maaytah M, Duffield J, Spencer P, Rosenberg M, Corry D, Saad S, Lenton P, Majerus G, and Nachnani S.: Study on the organoleptic intensity scale for measuring oral malodor, J. Am. Dent. Assoc., 136, 749757, (2005).

16) Osada K, Hanawa M, Tsunoda K, Izumi H.: Evaluation of the masking of dimethyl sulfide odors by citronellal, limonene and citral through the use of trained odor sensor mice, Chem. Senses., 38, 57-65, (2013)

17) Shirasu M, Nagai S, Hayashi R, Ochiai A, and Touhara K.: Dimethyl trisulfide as a characteristic odor associated with fungating cancer wounds, Biosci. Biotechnol. Biochem., 73, 2117-2120, (2009).

18) Haze S, Gozu Y, Nakamura S, Kohno Y, Sawano K, Ohta H, and Yamazaki K.: 2-Nonenal newly found in human body odor tends to increase with aging, J. Invest. Dermatol., 116, 520-524, (2001).

19) Kanda F, Yagi E, Fukuda M, Nakajima K, Ohta T, and Nakata O.: Elucidation of chemical compounds responsible for foot malodor, Br. J. Dermatol., 122, 771-776, (1990).

20) Franz M, Arafat HA, Pinto NG.: Effect of chemical surface heterogeneity on the adsorption mechanism of dissolved aromatics on activated carbon, Carbon, 38, 1807-1819, (2000).

21) Pan B and Xing B.: Adsorption mechanisms of organic chemicals on carbon nanotube, Environmental Science \& Technology, 42, 9005-9013, (2008).

22) Li L, Sun Z, Li H, Keener TC.: Effects of activated carbon surface properties on the adsorption of volatile organic compounds, J Air Waste Manag Assoc, 10, 1196-202, (2012).

23) Taylor R.: Interpretation of the correlation coefficient; A basic review, JDMS, 6, 35-39, (1990).

24) Zulkefli1 NN, Masdar MS, Isahak WNRW, Jahim JM, Rejab SAMM, Lye CC.: Removal of hydrogen sulfide from a biogas mimic by using impregnated activated carbon adsorbent, PLoS One, 14, 1-25, (2019).

25) Wang H, Lashaki MJ, Fayaz M, Hashisho Z, Philips JH, Anderson JE, Nichols M.: Adsorption and desorption of mixtures of organic vapors on beaded activated carbon, Environ. Sci. Technol., 46, 8341-8350, (2012).

26) Yoko Nishi and Michio Inagaki (ed. Michio Inagaki and Feiyu Kang): (2016), Gas Adsorption/Desorption Isotherm for Pore Structure Characterization, in Materials Science and Engineering of Carbon: Characterization, p227-247, Butterworth-Heinemann. 


\title{
天然物からの消臭活性物質の探索とシネオールの消臭作用の特性
}

\author{
邊見篤史 ${ }^{1}$, 杉野 努 $^{1}$, 中村健一 ${ }^{1}$, 野村正人 ${ }^{2}$, 奧原正國 ${ }^{1 *}$ \\ 1 リリース科学工業株式会社, $\bar{\top} 532-0033$ 大阪市淀川区新高 5-13-7 \\ 2 近畿大学工学部, $\overline{7} 739-2116$ 広島県東広島市高屋うめの市 1
}

\begin{abstract}
要旨：天然物由来の新しい消臭物質の発見を目的として，活性の測定にガスクロマトグラフィー $(\mathrm{GC})$ を 用いて，植物抽出物からのスクリーニングを試みた，その結果，フユアオイの $50 \%$ エタノール水による抽 出物に消臭活性を検出した. 活性の本体をシリカゲルカラムクロマトグラフィーにより精製し，1,8-シネオー ルと同定した，1,8-シネオールは，比較的広い範囲の悪臭ガス（2-ノネナール，スカトール，インドール， ジメチルトリスルフィド，ジメチルジスルフィド，イソ吉草酸）に対して，消臭率 $90 \%$ 以上の強い活性を 示した。また，アリルメチルスルフィド，酪酸，アリルメルカプタン，ジメチルスルフィドに対し $70 \%$ 以 上の消臭率を示した，な扔，消臭活性の強さを表す消臭率は，消臭物質を含むin vitroの測定系に悪臭ガス を添加して反応させ, その際に消失したガス量の原ガス量に対する割合 (\%) である. 官能試験 (6段階評価) では，1,8-シネオールは臭気強度を 1.5 3 段階低減させた。 1,8-シネオールには, 芳香によって臭気強度を 低下させるマスキング効果が知られている。一方，1,8-シネオールは消臭活性の強さと分子量，または消臭 活性と沸点との間に相関関係が認められた。また $1,8-$ シネオールに一旦吸着された悪臭ガスは高温で物理的 に脱着した。これらの知見から，1,8-シネオールにはマスキング以外に，悪臭ガスを吸着することにより， その濃度を低下させる物理的機序の存在が推定された。
\end{abstract}

キーワード：シネオール，覀臭，消臭活性，疎水性相互作用 